\title{
EFFECTIVENESS OF MATERIAL USING CT SCAN AND MRI \\ AFTER USE OF PICTURE ARCHIVING AND COMMUCATING \\ SYSTEM AND RADIOLOGY INFORMATION SYSTEM \\ AT RADIOLOGICAL INSTALLATION OF BUKITTINGGI \\ NATIONAL HOSPITAL, WEST SUMATRA
}

\author{
Widya $^{1}$, Adang Bachtiar²) \\ 1)Postgraduate Administrative Studies, Faculty of Public Health, \\ Universitas Indonesia \\ 2) Faculty of Public Health, Universitas Indonesia
}

\begin{abstract}
Background: Efficiency while paying attention to service quality is the top priority of the hospital. The efficiency in radiology installations has also not gone unnoticed. The implementation of Picture Archiving and Commucating System (PACS) and Radiology Information System (RIS) is one of the efforts to control costs in radiology installations, especially in consumables' efficiency (BHP). Bukittinggi National Stroke Hospital (RSSN), as one of the vertical hospitals located in the City of Bukittinggi, West Sumatra, has become a precursor to the implementation of PACS and RIS in this province. This study aimed to determine effect of material using ct scan and mri after use of picture archiving and communicating system and radiology information system at radiological installation of Bukittinggi national hospital, West Sumatra.

Subjects and Method: This was a descriptive study conducted at Radiological Installation Of Bukittinggi National Hospital, West Sumatra from July 2020. The data were collected by observation and monthly report data.

Results: The results of the analysis of the use of PACS and RIS had a significant impact on the cost efficiency of BHP CT scans and MRIs in the RSSN radiology installation reaching 97.9\%.

Conclusion: Transfer of CT scan and MRI results from film to DVD-R for internal RSSN patients with considerable efficiency.
\end{abstract}

Keyword: PACS, RIS, cost control, BHP

Correspondence:

Widya. Postgraduate Administrative Studies, Faculty of Public Health, Universitas Indonesia. Pondok Cina, Kecamatan Beji, Kota Depok, Jawa Barat 12345. Email: mnwidya@gmail.com. Mobile: (021) 7864975

The $7^{\text {th }}$ International Conference on Public Health Solo, Indonesia, November 18-19, 2020 391 https://doi.org/10.26911/the7thicph.05.23 